\title{
Cellular immune responses in amniotic fluid of women with preterm labor and intra-amniotic infection or intra-amniotic inflammation
}

\author{
Nardhy Gomez-Lopez ${ }^{1,2,3}$ (D) ～Roberto Romero ${ }^{1,4,5,6,7,8}$ (D) ～Jose Galaz ${ }^{1,2}$ | Yi Xu' ${ }^{1,2}$ | \\ Bogdan Panaitescu ${ }^{2}$ | Rebecca Slutsky ${ }^{1}$ | Kenichiro Motomura ${ }^{1,2}$ | Navleen Gill ${ }^{1,2}$ | \\ Robert Para $^{1,2}$ | Percy Pacora ${ }^{1,2}$ | Eunjung Jung ${ }^{1,2}$ | Chaur-Dong Hsu ${ }^{1,2,9}$
}

${ }^{1}$ Perinatology Research Branch, Division of Obstetrics and Maternal-Fetal Medicine, Division of Intramural Research, Eunice Kennedy Shriver National Institute of Child Health and Human Development, National Institutes of Health, U. S. Department of Health and Human Services, Detroit, MI, USA

${ }^{2}$ Department of Obstetrics and Gynecology, Wayne State University School of Medicine, Detroit, MI, USA

${ }^{3}$ Department of Immunology, Microbiology and Biochemistry, Wayne State University School of Medicine, Detroit, MI, USA

${ }^{4}$ Department of Obstetrics and Gynecology, University of Michigan, Ann Arbor, MI, USA

${ }^{5}$ Department of Epidemiology and Biostatistics, Michigan State University, East Lansing, MI, USA

${ }^{6}$ Center for Molecular Medicine and Genetics, Wayne State University, Detroit, MI, USA

${ }^{7}$ Detroit Medical Center, Detroit, MI, USA

${ }^{8}$ Department of Obstetrics and Gynecology, Florida International University, Miami, FL, USA

${ }^{9}$ Department of Physiology, Wayne State University School of Medicine, Detroit, MI, USA

\section{Correspondence}

Nardhy Gomez-Lopez, Department of Obstetrics and Gynecology, Wayne State University School of Medicine, Perinatology Research Branch, NICHD/NIH/DHHS, 275 E. Hancock, Detroit, MI 48201, USA.

Emails: nardhy.gomez-lopez@wayne.edu; ngomezlo@med.wayne.edu

Roberto Romero, Perinatology Research Branch, NICHD/NIH/DHHS, Hutzel Women's Hospital, 3990 John R, Box 4, Detroit, MI, 48201, USA.

Email: prbchiefstaff@med.wayne.edu

\section{Funding information}

This research was supported, in part, by the Perinatology Research Branch (PRB), Division of Obstetrics and Maternal-Fetal Medicine, Division of Intramural Research, Eunice Kennedy Shriver National Institute of Child Health and Human Development, National Institutes of Health, U. S. Department of Health and Human Services (NICHD/NIH/DHHS), and, in part, with federal funds from the NICHD/NIH/DHHS under Contract No. HHSN275201300006C. This research was also supported by the Wayne State University Perinatal Initiative in Maternal, Perinatal and Child Health.

\begin{abstract}
Problem: Preterm birth is commonly preceded by preterm labor, a syndrome that is causally linked to both intra-amniotic infection and intra-amniotic inflammation. However, the stereotypical cellular immune responses in these two clinical conditions are poorly understood.

Method of study: Amniotic fluid samples $(n=26)$ were collected from women diagnosed with preterm labor and intra-amniotic infection (amniotic fluid IL-6 concentrations $\geq 2.6 \mathrm{ng} / \mathrm{mL}$ and culturable microorganisms, $\mathrm{n}=10$ ) or intra-amniotic inflammation (amniotic fluid IL-6 concentrations $\geq 2.6 \mathrm{ng} / \mathrm{mL}$ without culturable microorganisms, $n=16$ ). Flow cytometry was performed to evaluate the phenotype and number of amniotic fluid leukocytes. Amniotic fluid concentrations of classical proinflammatory cytokines, type 1 and type 2 cytokines, and T-cell chemokines were determined using immunoassays.

Results: Women with spontaneous preterm labor and intra-amniotic infection had (a) a greater number of total leukocytes, including neutrophils and monocytes/macrophages, in amniotic fluid; (b) a higher number of total T cells and $\mathrm{CD} 4^{+} \mathrm{T}$ cells, but not $\mathrm{CD}^{+} \mathrm{T}$ cells or $\mathrm{B}$ cells, in amniotic fluid; and (c) increased amniotic fluid concentrations of IL-6, IL-1 $\beta$, and IL-10, compared to those with intra-amniotic inflammation. However, no differences in amniotic fluid concentrations of T-cell cytokines and chemokines were observed between these two clinical conditions.
\end{abstract}


Conclusion: The cellular immune responses observed in women with preterm labor and intra-amniotic infection are more severe than in those with intra-amniotic inflammation, and neutrophils, monocytes/macrophages, and $\mathrm{CD} 4^{+} \mathrm{T}$ cells are the main immune cells responding to microorganisms that invade the amniotic cavity. These findings provide insights into the intra-amniotic immune mechanisms underlying the human syndrome of preterm labor.

\section{KEYWORDS}

chorioamnionitis, fetal inflammatory response syndrome, funisitis, microbial invasion of the amniotic cavity, placental inflammation, pregnancy

\section{$1 \mid$ INTRODUCTION}

Preterm birth remains one of the most common obstetrical syndromes today and is a primary cause of perinatal morbidity and mortality worldwide. ${ }^{1-5}$ On average, two-thirds of all preterm births are preceded by spontaneous preterm labor, ${ }^{6}$ a syndrome of multiple etiologies. ${ }^{7}$ Of all the proposed causes of preterm labor, intra-amniotic inflammation/ infection has been causally linked to preterm birth. ${ }^{8-17}$ Intra-amniotic inflammation can result from microbial invasion of the amniotic cavity, which is referred to as intra-amniotic infection., ${ }^{90,12,18-29}$ Yet, inflammation in the amniotic cavity can also occur in the absence of culturable microorganisms, which is simply known as intra-amniotic inflammation. ${ }^{16,27,30}$ Recently, we showed using molecular microbiological techniques that a subset of patients with preterm labor and intra-amniotic inflammation do not have detectable bacteria in the amniotic cavity, which we termed sterile intra-amniotic inflammation. ${ }^{31-34}$ This condition is associated with elevated concentrations of endogenous danger signals, or alarmins (molecules released upon cellular stress or damage ${ }^{35-37}$ ), in amniotic fluid; ${ }^{38-43}$ although of interest, it is not yet a clinical diagnosis as the use of molecular microbiological techniques is not common practice in obstetrics. Therefore, patients with preterm labor are either diagnosed with intra-amniotic infection or intra-amniotic inflammation. Although both clinical conditions are associated with preterm labor and adverse neonatal outcomes, ${ }^{32,44}$ their management is different (intra-amniotic infection is treated with antibiotics ${ }^{45}$ ), and only intra-amniotic infection is linked to maternal morbidity and mortality. ${ }^{46}$ Therefore, elucidating the stereotypical immune responses in intra-amniotic infection and intra-amniotic inflammation is essential for understanding these clinical conditions.

Flow cytometry has emerged as a cutting-edge technique for the evaluation of immune cells in small volumes of biological fluids such as cerebrospinal fluid, ${ }^{47,48}$ urine, ${ }^{49-51}$ ascitic fluid, ${ }^{52}$ and sputum ${ }^{53}$ in the clinical setting. Indeed, flow cytometry has been utilized to identify specific immune cell types, as well as their expressed mediators, in amniotic fluid of women with intra-amniotic inflammation/ infection and clinical chorioamnionitis at term. ${ }^{54,55}$ This technique also allowed for the identification of the newly described innate lymphoid cells in the amniotic cavity of women during the second trimester. ${ }^{55,56}$ Herein, we utilized flow cytometry to characterize the cellular immune responses in the amniotic cavity of women diagnosed with preterm labor and intra-amniotic infection or intraamniotic inflammation.

\section{2 | MATERIALS AND METHODS}

\section{1 | Study population and characteristics}

This cross-sectional study included patients who underwent transabdominal amniocentesis due to clinical indications. The collection of samples was approved by the Institutional Review Boards of the Detroit Medical Center (Detroit, MI, USA), Wayne State University, and the Perinatology Research Branch, an intramural program of the Eunice Kennedy Shriver National Institutes of Health, National Institutes of Health,US Department of Health and Human Services (NICHD/NIH/DHHS). All women provided written informed consent prior to the collection of amniotic fluid. This study included 26 amniotic fluid samples (collected from 2013 to 2016) from women classified into the following groups: (a) women with spontaneous preterm labor who delivered preterm with intra-amniotic inflammation ( $\mathrm{n}=16$ ) and (b) women with spontaneous preterm labor who delivered preterm with intra-amniotic infection $(n=10)$ (see diagnostic criteria below). For all patients who delivered preterm, the time between the collection of the amniotic fluid sample and delivery was $\leq 7$ days. Demographic and clinical characteristics of the study population are shown in Table 1.

\section{2 | Clinical definitions}

Gestational age was determined by the date of the last menstrual period and confirmed by ultrasound examination. The gestational age derived from sonographic fetal biometry was used if the estimation was inconsistent with menstrual dating. Spontaneous preterm labor was diagnosed by the presence of regular uterine contractions (at least two contractions every 10 minutes) associated with cervical changes in patients $<37$ weeks of gestation. Microbial invasion of the amniotic cavity (MIAC) was defined as a positive amniotic fluid culture, including genital mycoplasmas. ${ }^{9,10,22,57,58}$ Intra-amniotic inflammation was defined as an amniotic fluid IL-6 concentration $\geq 2.6 \mathrm{ng} / \mathrm{mL}$ in the absence of culturable bacteria. ${ }^{27,59-64}$ Intra-amniotic infection was defined as the presence of MIAC together with intra-amniotic inflammation. ${ }^{31-33,65-74}$ 
TAB LE 1 Clinical and demographic characteristics of women who underwent spontaneous preterm labor

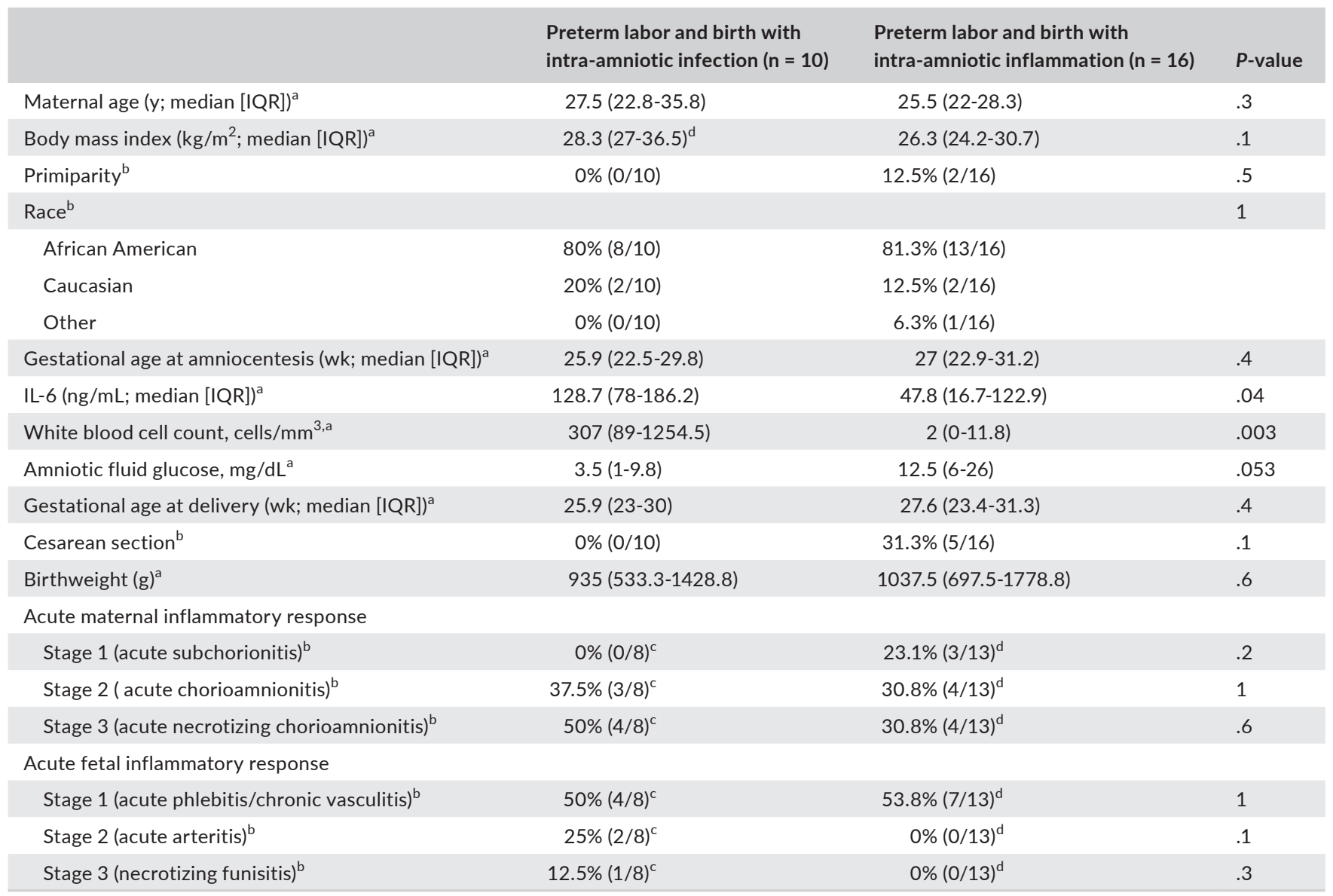

Note: Data are given as median (interquartile range, IQR) and percentage $(\mathrm{n} / \mathrm{N})$.

${ }^{a}$ Mann-Whitney $U$ test.

${ }^{\mathrm{b}}$ Fisher's exact test.

'Two missing data.

${ }^{\mathrm{d}}$ Three missing data.

\section{3 | Placental histopathological examination}

Placentas were examined histologically by perinatal pathologists blinded to clinical diagnoses and obstetrical outcomes according to standardized Perinatology Research Branch protocols. ${ }^{75,76}$ Briefly, three to nine sections of the placenta were examined, and at least one full-thickness section was taken from the center of the placenta; others were taken randomly from the placental disk. Acute inflammatory lesions of the placenta (maternal inflammatory response and fetal inflammatory response) were diagnosed according to established criteria, including staging and grading. ${ }^{75,77}$ The proportions of patients whose placentas presented acute maternal and/or fetal inflammatory responses are displayed in Table 1.

\subsection{Amniotic fluid sample collection}

Amniotic fluid samples were obtained by transabdominal amniocentesis under antiseptic conditions and monitored by ultrasound in order to detect intra-amniotic inflammation and/or infection in patients with preterm labor. Samples of amniotic fluid were transported to the laboratory in a sterile, capped syringe and immunophenotyping was performed immediately. The rest of the sample was centrifuged at $1300 \mathrm{~g}$ for 10 minutes at $4^{\circ} \mathrm{C}$, and the supernatant was stored at $-80^{\circ} \mathrm{C}$ until use. Also, an aliquot of amniotic fluid was transported to the clinical laboratory for culture of aerobic/anaerobic bacteria and genital mycoplasmas. The clinical tests also included the determination of an amniotic fluid white blood cell count, ${ }^{78}$ a Gram stain examination, ${ }^{79}$ a glucose concentration, ${ }^{80}$ and an IL-6 concentration. ${ }^{27}$

\subsection{Determination of IL-6 in amniotic fluid}

Amniotic fluid concentrations of IL- 6 were determined by using a sensitive and specific enzyme immunoassay obtained from R\&D Systems (Minneapolis, MN, USA). The IL-6 concentrations were determined by interpolation from the standard curve. The inter- and intra-assay coefficients of variation for IL-6 were $8.7 \%$ and $4.6 \%$, respectively. The detection limit of the IL-6 assay was $0.09 \mathrm{pg} / \mathrm{mL}$. The IL-6 concentrations in amniotic fluid were determined for clinical purposes. 


\section{6 | Immunophenotyping by flow cytometry}

Amniotic fluid samples (0.5-1 mL) were centrifuged at $300 \mathrm{~g}$ for 5 minutes at room temperature. The resulting amniotic fluid pellet was resuspended in $1 \mathrm{~mL}$ of $1 \mathrm{X}$ phosphate-buffered saline (PBS) (Life Technologies, Grand Island, NY, USA) and stained with BD Horizon Fixable Viability Stain 510 dye (BD Biosciences, San Jose, CA, USA). Cells were washed in 1X PBS and incubated with $20 \mu \mathrm{L}$ of human FcR blocking reagent (Miltenyi Biotec, San Diego, CA, USA) in $80 \mu \mathrm{L}$ of stain buffer (BD Biosciences) for 10 minutes at $4^{\circ} \mathrm{C}$. Next, cells were incubated with extracellular fluorochrome-conjugated anti-human monoclonal antibodies for 30 minutes at $4^{\circ} \mathrm{C}$ in the dark (Table S1). Stained cells were then washed with $1 \mathrm{X}$ PBS, resuspended in $0.5 \mathrm{~mL}$ of stain buffer, and acquired using the BD LSR II or LSRFortessa Flow Cytometer (BD Bioscience) and BD FACSDiva 6.0 software (BD Bioscience). The analysis was performed, and the figures were generated using the FlowJo version 10 software (FlowJo, Ashland, OR, USA). The absolute number of cells was determined using CountBright absolute counting beads (Molecular Probes, Eugene, OR, USA).

\section{7 | Amniotic fluid cytokine/chemokine concentrations}

Amniotic fluid samples were assessed using the V-PLEX Proinflammatory Panel 1 kit (Meso Scale Discovery, Rockville, MD, USA) to measure amniotic fluid concentrations of IFN- $\gamma$, TNF- $\alpha$, IL-1 $\beta$, IL-2, IL-4, IL-6, IL-8, IL-10, IL-12p70, and IL-13, according to the manufacturer's instructions. Plates were read using the SECTOR 2400 Imager (Meso Scale Discovery). Standard curves were generated, and the assay values of the samples were interpolated from the curves. The detection limits of the assays were $0.37 \mathrm{pg} / \mathrm{mL}(\mathrm{IFN}-\gamma)$, $0.04 \mathrm{pg} / \mathrm{mL}$ (TNF- $\alpha$ ), $0.05 \mathrm{pg} / \mathrm{mL}$ (IL-1 $\beta$ ), $0.09 \mathrm{pg} / \mathrm{mL}$ (IL-2), $0.02 \mathrm{pg}$ / $\mathrm{mL}$ (IL-4), $0.06 \mathrm{pg} / \mathrm{mL}$ (IL-6), $0.07 \mathrm{pg} / \mathrm{mL}$ (IL-8), $0.04 \mathrm{pg} / \mathrm{mL}$ (IL-10), $0.11 \mathrm{pg} / \mathrm{mL}$ (IL-12p70), and $0.24 \mathrm{pg} / \mathrm{mL}$ (IL-13). Inter-assay and intraassay coefficients of variation were $<10.5 \%$.

Amniotic fluid concentrations of CXCL10 (Cat\#DIP100, R\&D Systems) and CXCL11 (Cat\#K151UWK-1, Meso Scale Discovery) were determined using individual sensitive and specific immunoassays, according to the manufacturers' instructions. The concentrations of CXCL10 and CXCL11 were determined by interpolation from the standard curve. The detection limits of the assays were $1.67 \mathrm{pg} / \mathrm{mL}$ (CXCL10) and $1.5 \mathrm{pg} / \mathrm{mL}$ (CXCL11). The inter-assay and intra-assay coefficients of variation were less than $9.8 \%$ for CXCL10 and less than $16.8 \%$ for CXCL11.

\section{8 | Statistical analysis}

Statistical analyses were conducted using SPSS software version 19.0 (IBM Corporation, Armonk, NY, USA). For patient demographics, the Mann-Whitney $U$ test was performed for continuous variables and Fisher's exact test for nominal variables. The MannWhitney $U$ test was also performed when comparing cell numbers and cytokine/chemokine concentrations between the study groups. A $P$-value $<.05$ was considered statistically significant.

\section{3 | RESULTS}

\subsection{Characteristics of the study population}

The demographic and clinical characteristics of the study population are shown in Table 1. A total of 26 amniotic fluid samples were collected from women who underwent spontaneous preterm labor and birth either with intra-amniotic infection $(n=10)$ or with intra-amniotic inflammation $(n=16)$. Amniotic fluid concentrations of IL-6 and white blood cell counts were higher in women with preterm labor and intra-amniotic infection compared to those with intra-amniotic inflammation (Table 1). Glucose concentrations tended to be lower in women with intra-amniotic infection compared to those with intraamniotic inflammation (Table 1). Women with intra-amniotic inflammation and those with intra-amniotic infection presented acute maternal and fetal inflammatory responses in the placenta (Table 1). The following microorganisms were detected in women diagnosed with intra-amniotic infection: Ureaplasma urealyticum, Mycoplasma hominis, Fusobacterium spp., Candida spp., Gardnerella vaginalis, Peptostreptococcus, Streptococcus serogroup C, and Enterococcus faecalis.

\section{2 | Leukocyte populations in amniotic fluid of women with preterm labor and intra-amniotic inflammation or intra-amniotic infection}

Figure $1 A, C$ shows representative images of the flow cytometry gating strategy used to detect leukocytes in amniotic fluid from women with preterm labor and intra-amniotic inflammation (Figure 1A) or intra-amniotic infection (Figure 1C). Representative $\mathrm{t}$-SNE plots illustrate the amniotic fluid leukocyte populations found in the two study groups (Figure 1B,D). Notably, more women with preterm labor and intra-amniotic infection (80\%) displayed a high proportion of neutrophils and monocytes/macrophages in amniotic fluid compared to those with intra-amniotic inflammation without detectable microorganisms (50\%; Figure 1D vs $1 B$ ). Indeed, the abundant neutrophils and monocytes/macrophages in amniotic fluid of women with intra-amniotic infection masked the other immune cell types (eg, T cells and B cells) that are clearly identified in women with intra-amniotic inflammation (Figure 1D vs $1 \mathrm{~B})$.

We then quantified the numbers of total leukocytes in amniotic fluid from the two study groups. Women with preterm labor and intra-amniotic infection had greater total numbers of leukocytes in amniotic fluid compared to those with intra-amniotic inflammation (Figure 2A). Quantification of neutrophils (CD15 ${ }^{+}$leukocytes) and monocytes/macrophages (CD14 ${ }^{+}$leukocytes) in amniotic fluid showed that the numbers of these innate immune cells were greater in women with intra-amniotic infection compared to those with intra-amniotic inflammation (Figure 2B,C), mirroring the relative differences observed between the t-SNE plots in Figure 1.

We previously demonstrated that adaptive immune cells (ie, $T$ cells and B cells) are also present in amniotic fluid during normal 


\section{(A) Intra-amniotic inflammation}
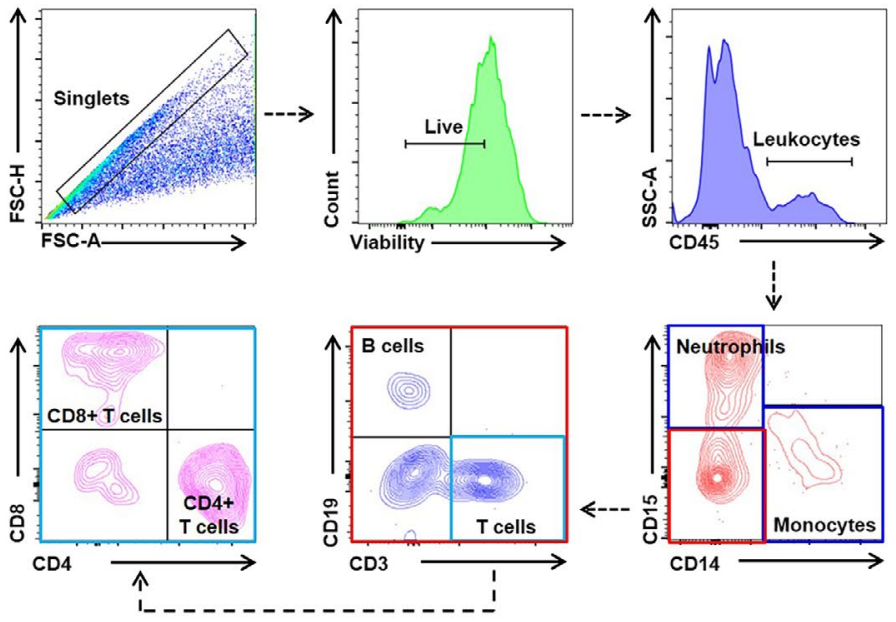

(C) Intra-amniotic infection
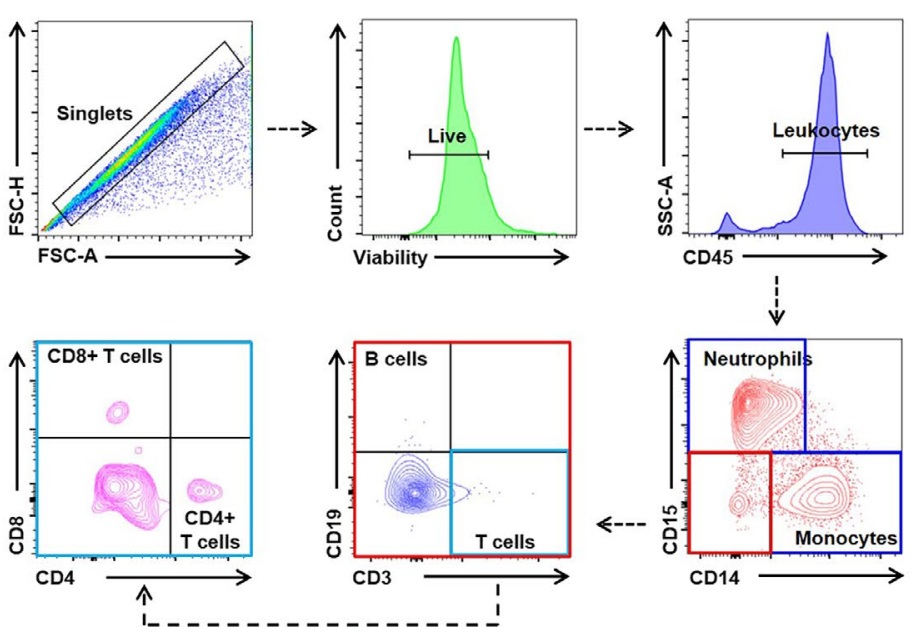

(B)

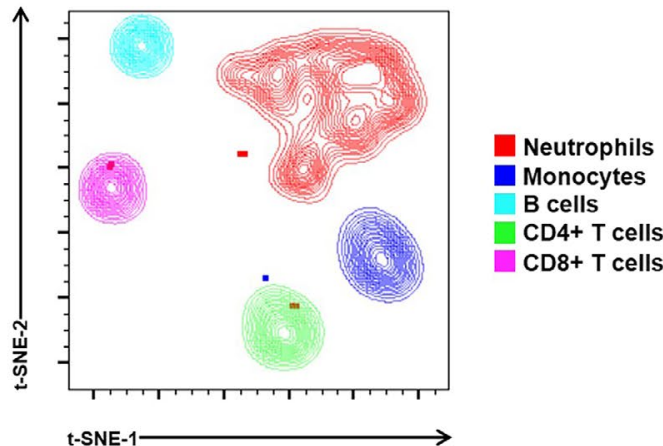

(D)

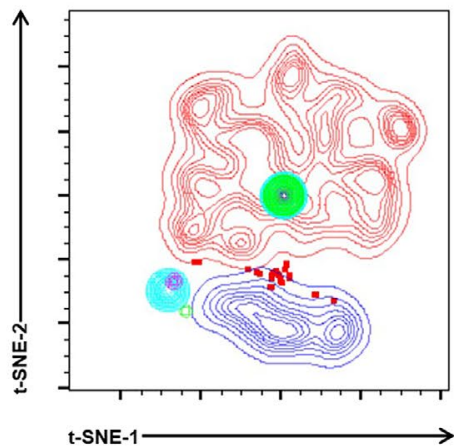

Neutrophils Monocytes

$B$ cells

CD4+ T cells

CD8+ T cells

FIGURE 1 Leukocyte populations in amniotic fluid. Representative flow cytometry gating strategies and t-distributed stochastic neighbor embedding (t-SNE) plots showing leukocyte populations in amniotic fluid from women who underwent spontaneous preterm labor and birth with intra-amniotic inflammation (A-B) or with intra-amniotic infection (C-D). Immune cells were initially gated within the viability gate and $\mathrm{CD} 45^{+}$gate, followed by lineage gating for neutrophils (CD $45^{+} \mathrm{CD} 15^{+}$cells), monocytes/macrophages (CD45 ${ }^{+} \mathrm{CD} 14^{+}$cells), $\mathrm{T}$ cells $\left(\mathrm{CD} 45^{+} \mathrm{CD} 3^{+}\right.$cells), which were subsequently gated for $\mathrm{CD} 4^{+} \mathrm{T}$ cells $\left(\mathrm{CD} 45^{+} \mathrm{CD} 3^{+} \mathrm{CD} 4^{+}\right.$cells) and $\mathrm{CD} 8^{+} \mathrm{T}$ cells $\left(\mathrm{CD} 45^{+} \mathrm{CD} 3^{+} \mathrm{CD} 8^{+}\right.$cells), and $\mathrm{B}$ cells $\left(\mathrm{CD} 45^{+} \mathrm{CD} 19^{+}\right.$cells). Plots are representative of $10-16$ samples per group

pregnancy. ${ }^{55}$ Therefore, we then determined whether the numbers of such cells were altered in amniotic fluid from our two study groups. We found that the total T-cell population (CD3 ${ }^{+}$leukocytes) and $\mathrm{CD} 4^{+} \mathrm{T}$ cells were significantly increased in women with preterm labor and intra-amniotic infection compared to those with intra-amniotic inflammation (Figure 3A,B). The numbers of $\mathrm{CD}^{+} \mathrm{T}$ cells were also higher in women with preterm labor and intra-amniotic infection compared to those with intra-amniotic inflammation, although this was not significant (Figure 3C). Lastly, we determined the numbers of B cells (CD19+ leukocytes) and found no statistical differences between the two study groups (Figure 3D).

Together, these results indicate that total leukocytes, as well as specific leukocyte subsets, namely neutrophils, monocytes/macrophages, and $\mathrm{CD} 4^{+} \mathrm{T}$ cells, are increased in amniotic fluid of women with preterm labor and intra-amniotic infection compared to those with intra-amniotic inflammation.

\subsection{Cytokine and chemokine concentrations in amniotic fluid of women with preterm labor and intra- amniotic inflammation or intra-amniotic infection}

Next, we investigated whether the increased numbers of amniotic fluid leukocytes in women with preterm labor and intra-amniotic infection were associated with an increase in cytokine concentrations. We found that the concentrations of the pro-inflammatory cytokines IL-6 and IL-1 $\beta$ were both significantly elevated in amniotic fluid of women with preterm labor and intra-amniotic infection compared to those with intra-amniotic inflammation (Figure $4 A, B$ ). In contrast, 

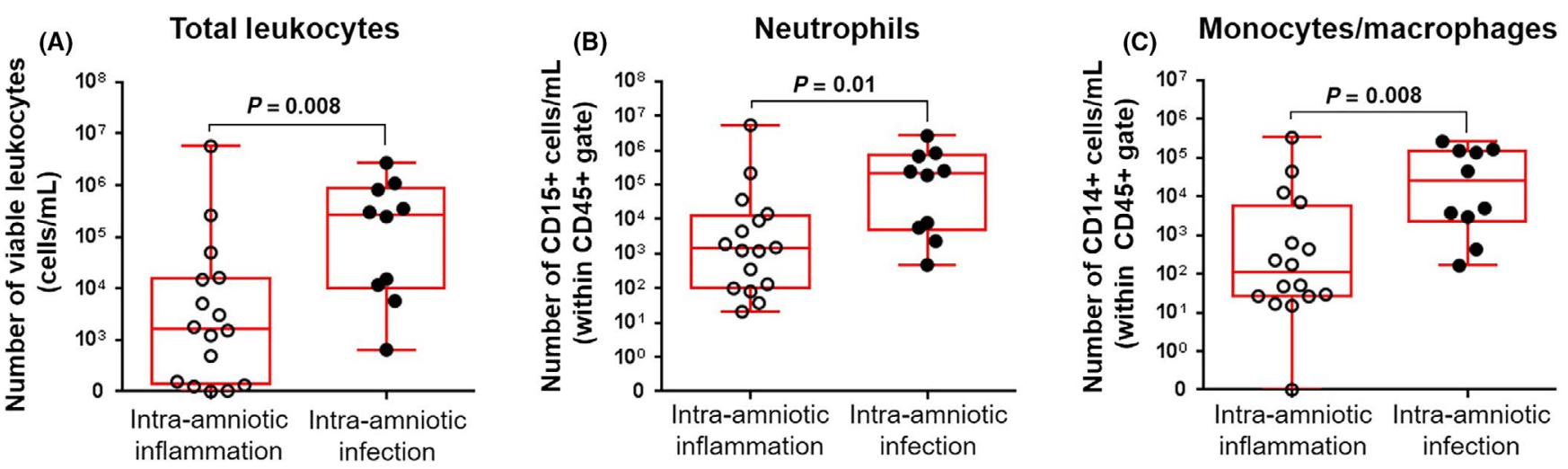

FIGURE 2 Total leukocytes and innate immune cells in amniotic fluid. Numbers of (A) total leukocytes (CD45 $5^{+}$cells $\left./ \mathrm{mL}\right),(B) \mathrm{neutrophils}$ $\left(\mathrm{CD} 15^{+}\right.$cells $\left./ \mathrm{mL}\right)$, and $(C)$ monocytes $/$ macrophages $\left(\mathrm{CD} 14^{+}\right.$cells $\left./ \mathrm{mL}\right)$ in amniotic fluid from women who underwent spontaneous preterm labor and birth with intra-amniotic inflammation or with intra-amniotic infection. $\mathrm{N}=10-16$ per group. Midlines = medians, boxes $=$ interquartile ranges, and whiskers $=$ minimum $/$ maximum ranges

concentrations of IL-8 and IL-12p70 were not significantly different between women with preterm labor and intra-amniotic infection and those with intra-amniotic inflammation (Figure 4C,D).

As the numbers of amniotic fluid total $\mathrm{T}$ cells and $\mathrm{CD} 4^{+} \mathrm{T}$ cells were increased in women with intra-amniotic infection, the concentrations of type 1 and type 2 cytokines, as well as T-cell chemokines, were determined. The type 1 cytokines IL-2, IFN- $\gamma$, and TNF- $\alpha$ were not significantly different between women with intra-amniotic infection and those with intra-amniotic inflammation (Figure 5A-C). While IL-4 and IL-13 did not change, the amniotic fluid concentration of the type 2 cytokine IL-10 tended to increase in women with intra-amniotic infection compared to those with intra-amniotic inflammation (Figure 5D-F). No differences were observed in amniotic fluid concentrations of the Tcell chemokines CXCL10 and CXCL11 between the study groups (Figure 5G,H).
(A)

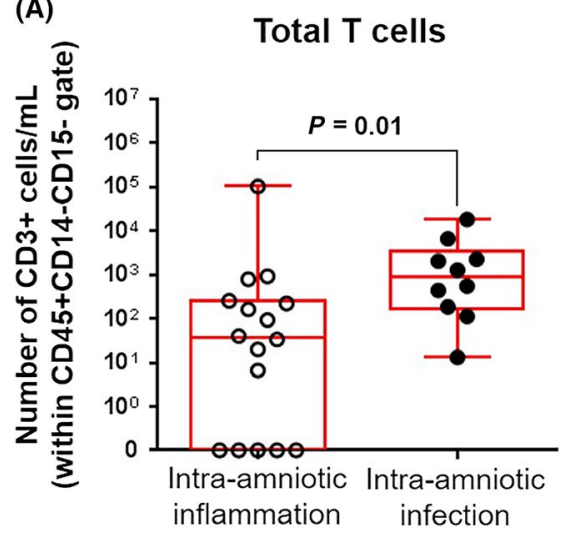

(C)

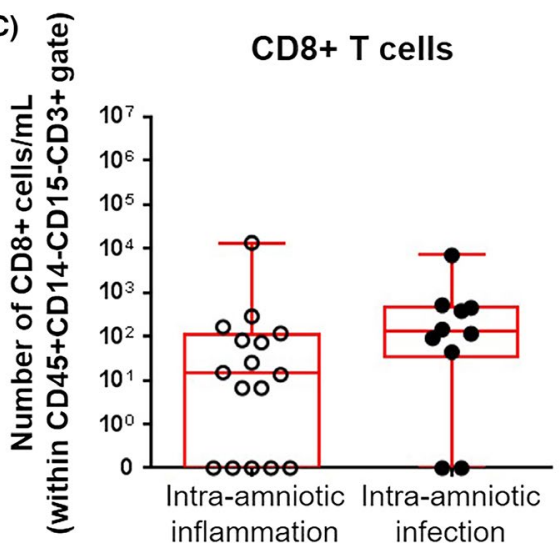

(B) Ф

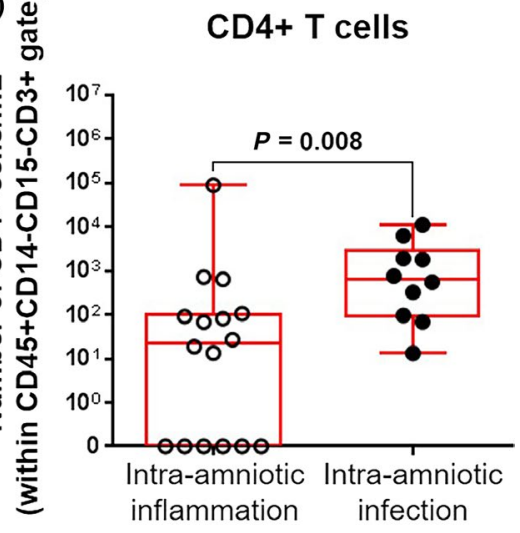

(D)

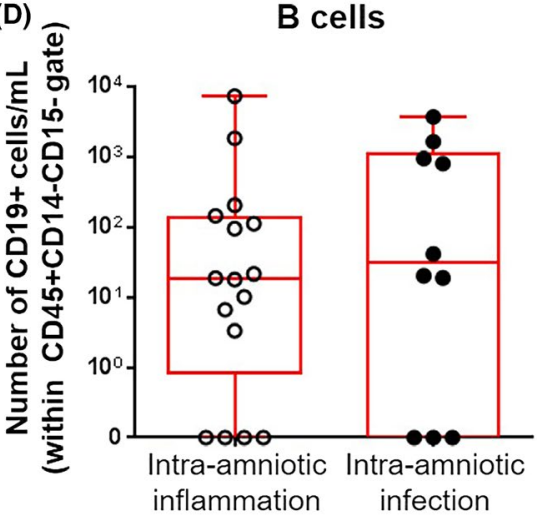

FIGURE 3 Adaptive immune cells in amniotic fluid. Numbers of (A) total T cells (CD3 ${ }^{+}$cells $/ \mathrm{mL}$ ), (B) $\mathrm{CD} 4^{+} \mathrm{T}$ cells (CD3 ${ }^{+} \mathrm{CD} 4^{+}$cells $/ \mathrm{mL}$ ), (C) $\mathrm{CD} 8^{+} \mathrm{T}$ cells $\left(\mathrm{CD}^{+}{ }^{+} \mathrm{CD} 8^{+}\right.$cells $/ \mathrm{mL}$ ), and (D) B cells $\left(\mathrm{CD} 19^{+}\right.$cells $\left./ \mathrm{mL}\right)$ in amniotic fluid from women who underwent spontaneous preterm labor and birth with intraamniotic inflammation or with intraamniotic infection. $\mathrm{N}=10-16$ per group. Midlines $=$ medians, boxes $=$ interquartile ranges, and whiskers $=$ minimum $/$ maximum ranges 


\section{4 | DISCUSSION}

\section{1 | Principal findings}

Herein, we report that women with spontaneous preterm labor and intra-amniotic infection had (a) a greater number of total leukocytes including neutrophils and monocytes/macrophages in amniotic fluid; (b) a higher number of total $\mathrm{T}$ cells and $\mathrm{CD} 4^{+} \mathrm{T}$ cells, but not $\mathrm{CD} 8^{+}$ $T$ cells or B cells, in amniotic fluid; and (c) increased amniotic fluid concentrations of IL-6, IL-1 $\beta$, and IL-10, compared to those with intraamniotic inflammation. However, no differences in amniotic fluid concentrations of T-cell cytokines and chemokines were observed between these two clinical conditions. Collectively, these results indicate that the cellular immune responses observed in women with preterm labor and intra-amniotic infection are more severe than in those with intra-amniotic inflammation and are characterized by an increased number of neutrophils, monocytes/macrophages, and CD4 ${ }^{+} \mathrm{T}$ cells.

\subsection{Amniotic fluid neutrophils in women with preterm labor and intra-amniotic infection or intra- amniotic inflammation}

It is well known that neutrophils are the most abundant immune cell type in the amniotic cavity of women with intra-amniotic infection and/or intra-amniotic inflammation. ${ }^{54,78,81,82}$ Yet, whether the number of amniotic fluid neutrophils differs between intra-amniotic inflammatory processes with and without culturable microorganisms has not been shown until now. Herein, we showed that the number of amniotic fluid neutrophils is higher in women with preterm labor and intra-amniotic infection than in those with intra-amniotic inflammation without culturable microorganisms, indicating that different thresholds in the number of these immune cells may allow for the differentiation of these two clinical conditions.

In women with preterm labor and intra-amniotic infection, as well as other pathogen-mediated immune responses, ${ }^{83,84}$ neutrophils participate in the main mechanisms of microbial killing: degranulation, phagocytosis, and neutrophil extracellular trap (NET) formation. For example, amniotic fluid neutrophils can produce reactive oxygen species ${ }^{85}$ and release antimicrobial molecules such as alpha-defensins, ${ }^{86-89}$ myeloperoxidase, ${ }^{29,89,90}$ cathepsin $\mathrm{G},{ }^{89,91}$ elastase, ${ }^{89,92,93}$ lactoferrin, ${ }^{94}$ pentraxin-3, ${ }^{95}$ and cathelicidin, ${ }^{29,89}$ all of which are found in the intra-amniotic space. Amniotic fluid neutrophils of fetal or maternal origin ${ }^{82}$ can also actively participate in killing microbes invading the amniotic cavity by performing phagocytosis ${ }^{96}$ and forming NETs. ${ }^{97}$ Indeed, NETs are also formed by maternal neutrophils invading the amniotic cavity ${ }^{97}$ and chorioamniotic membranes ${ }^{98,99}$ in cases with intra-amniotic infection. In addition to killing microbes, amniotic fluid neutrophils can release pro-inflammatory cytokines such as IL- 8, TNF- $\alpha$, MIP- $1 \alpha$, MIP-1 $\beta$, $\mathrm{IL}-1 \alpha$, and IL-1 $\beta$ into the intra-amniotic space in cases with MIAC and clinical chorioamnionitis at term. ${ }^{54}$ These cytokines have been implicated in the pathogenesis of preterm labor in the context of intra-amniotic infection. ${ }^{38,39,43,81,100-109}$ Specifically, IL-1 $\beta$ is a central mediator in the pathogenesis of preterm labor because the systemic $^{110,111}$ and intra-amniotic ${ }^{11,112-118}$ administration of this cytokine in pregnant animals induces preterm birth. The mechanisms whereby IL-1 $\beta$ induces preterm labor and birth, in the context of intra-amniotic infection, involve the nucleotide-binding oligomerization domain, leucine-rich repeat, and pyrin domain containing 3 (NLRP3) inflammasome, an intracellular multiprotein complex that can be activated in the fetal membranes by microbial products in mice (eg, lipopolysaccharide; LPS). ${ }^{119}$ Consistently, women with preterm labor and acute histologic chorioamnionitis (a placental lesion associated with intra-amniotic infection ${ }^{120-122}$ ) also display inflammasome activation in the amniotic fluid ${ }^{34}$ and chorioamniotic membranes. ${ }^{123}$ Together, these data indicate that amniotic fluid neutrophils participate in both the host defense and inflammatory mechanisms implicated in the pathogenesis of preterm labor and birth in women with intra-amniotic infection.

Women with intra-amniotic inflammation also had neutrophils in their amniotic fluid; however, the numbers were lower than in those with intra-amniotic infection. This finding shows that the mechanisms of inflammation occurring in women without culturable microorganisms in amniotic fluid are distinct from and less severe than in those with intra-amniotic infection. One possibility is that a subset
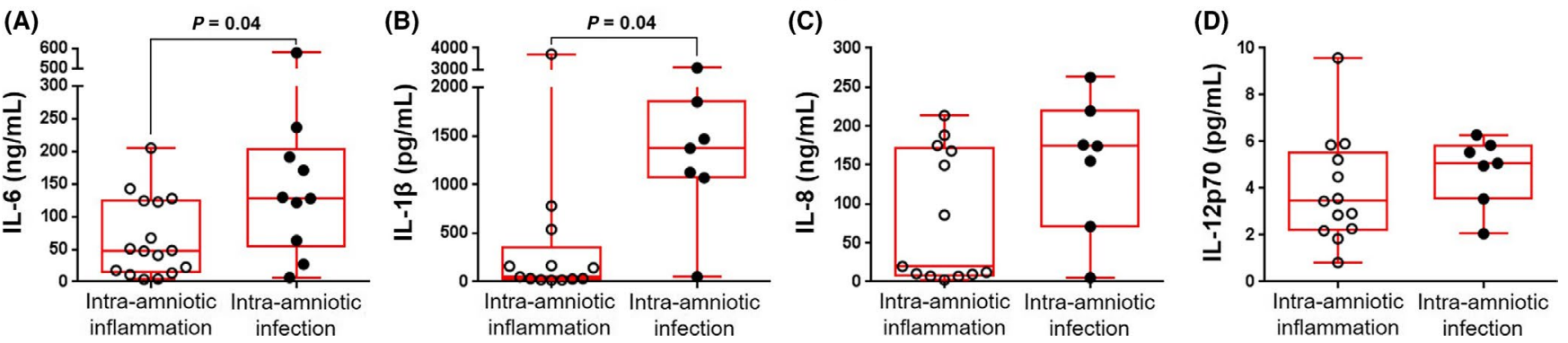

FIG URE 4 Pro-inflammatory cytokines in amniotic fluid. Concentrations of (A) IL-6 (ng/mL), (B) IL-1 (pg/mL), (C) IL-8 (ng/mL), and (D) IL-12p70 $(\mathrm{pg} / \mathrm{mL})$ in amniotic fluid from women who underwent spontaneous preterm labor and birth with intra-amniotic inflammation or with intra-amniotic infection. $\mathrm{N}=7-16$ per group. Midlines = medians, boxes $=$ interquartile ranges, and whiskers $=$ minimum $/$ maximum ranges 


\section{Type 1 cytokines}
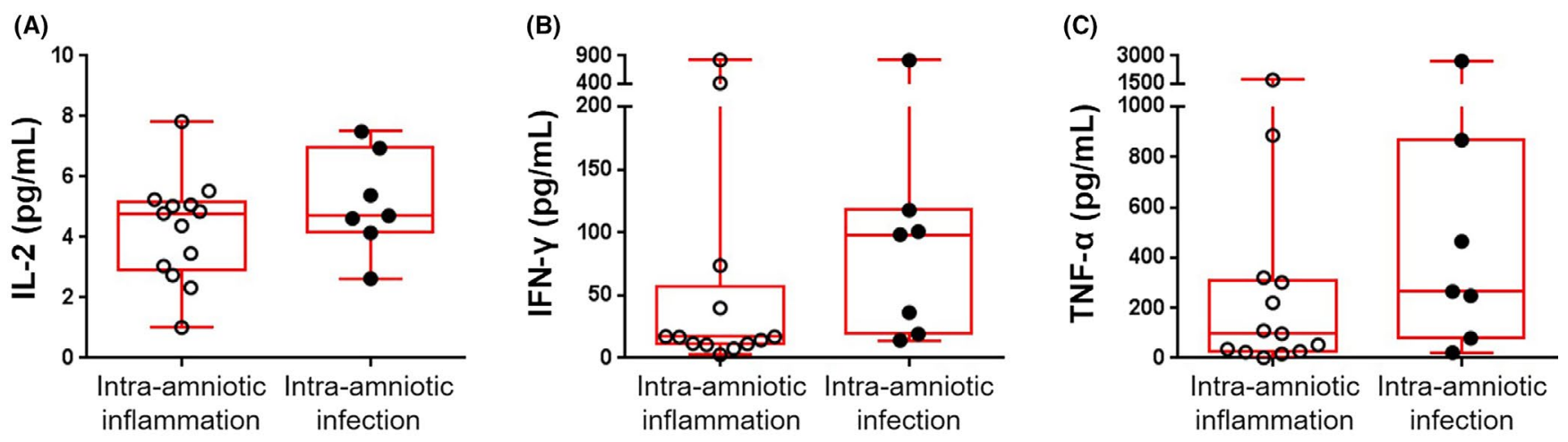

\section{Type 2 cytokines}
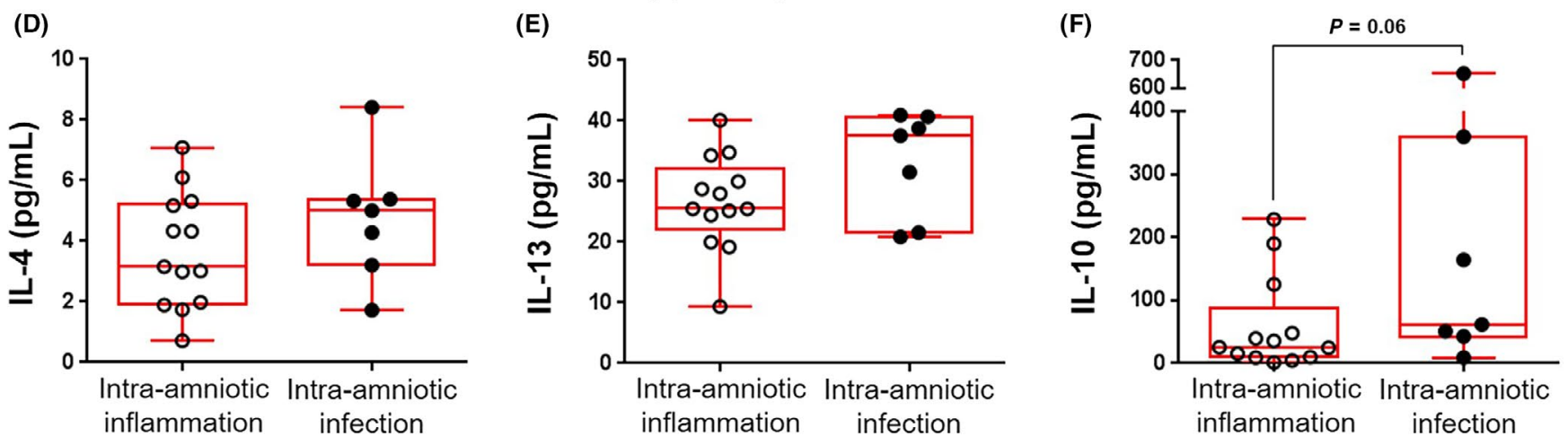

\section{T-cell chemokines}

(G)

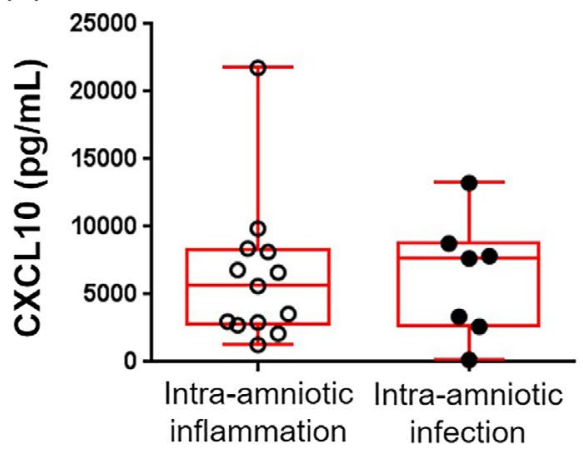

(H)

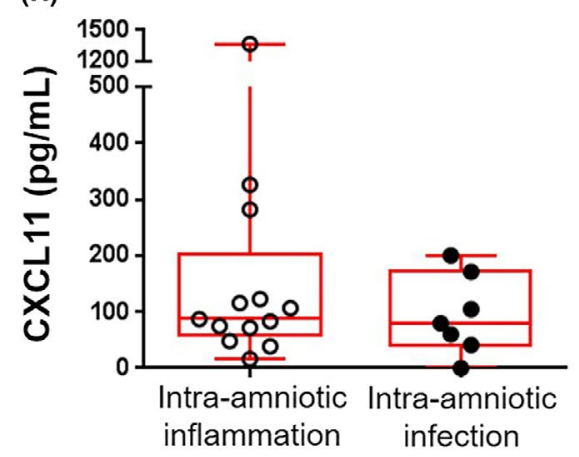

FIGURE 5 Type 1 and type 2 cytokines and T-cell chemokines in amniotic fluid. Concentrations of the type $1 \mathrm{cytokines} \mathrm{(A)} \mathrm{IL-2} \mathrm{(pg/mL),}$ (B) IFN- $\gamma(\mathrm{pg} / \mathrm{mL})$, and (C) TNF- $\alpha(\mathrm{pg} / \mathrm{mL})$; type 2 cytokines (D) IL-4 (pg/mL), (E) IL-13 (pg/mL), and (F) IL-10 (pg/mL); and T-cell chemokines (G) CXCL10 $(\mathrm{pg} / \mathrm{mL})$ and $(\mathrm{H})$ CXCL11 $(\mathrm{pg} / \mathrm{mL})$ in amniotic fluid from women who underwent spontaneous preterm labor and birth with intra-amniotic inflammation or with intra-amniotic infection. $\mathrm{N}=7-13$ per group. Midlines = medians, boxes = interquartile ranges, and whiskers $=$ minimum $/$ maximum ranges

of women who underwent preterm labor with intra-amniotic inflammation had elevated amniotic fluid concentrations of alarmins ${ }^{43}$ (eg, $\mathrm{IL}-1 \alpha,{ }^{39} \mathrm{HMGB} 1,{ }^{42,124} \mathrm{HSP}^{2} 0,{ }^{41}$ and $\mathrm{S} 100 \mathrm{~B}^{40}$ ), referred to as sterile intra-amniotic inflammation. ${ }^{32-34}$ Human studies have provided evidence that preterm labor with sterile intra-amniotic inflammation is less severe than preterm labor with microbial-induced intra-amniotic inflammation. ${ }^{34,43,125}$ Indeed, only $~ 50 \%$ of pregnant mice intra-amniotically injected with physiologically relevant concentrations of alarmins undergo preterm birth, ${ }^{126,127}$ whereas almost all of those injected with a microbial product (LPS) deliver preterm. ${ }^{128,129}$ The mechanisms whereby alarmins induced preterm labor and birth also involved the NLRP3 inflammasome; ${ }^{127,130}$ yet, these will be discussed below as sterile inflammation is mainly mediated by monocytes/macrophages. ${ }^{131,132}$ Taken together, these data consistently show that women with preterm labor and intra-amniotic inflammation without culturable microorganisms had a milder intra-amniotic 
inflammatory response, including a lower number of amniotic fluid neutrophils, than those with intra-amniotic infection.

It is worth mentioning that women with preterm labor and intra-amniotic inflammation may have been infected by non-culturable microorganisms. Microorganisms such as Sneathia spp., ${ }^{31,33,133}$ Neisseria spp., ${ }^{33,133}$ and Fusobacterium nucleatum ${ }^{31,134}$ have proven difficult to culture from amniotic fluid using traditional clinical methods. However, whether such non-culturable microorganisms can lead to a stronger intra-amniotic inflammatory response than that mediated by alarmins requires further investigation.

\subsection{Amniotic fluid monocytes/macrophages in women with preterm labor and intra-amniotic infection or intra-amniotic inflammation}

We also demonstrated that the number of monocytes/macrophages is increased in women with preterm labor and intra-amniotic infection compared to those with intra-amniotic inflammation. Monocytes/ macrophages are commonly found together with neutrophils in amniotic fluid of women with intra-amniotic infection and/or inflammation. ${ }^{54,78}$ As neutrophils typically represent the dominant immune cell population in such women, ${ }^{54,78}$ the functions of monocytes/ macrophages in the context of intra-amniotic infection or inflammation have been less investigated.

Monocytes are chemo-attracted to sites of inflammation, where they attain one of several different activation states depending on the microenvironment. ${ }^{135}$ Stimulation of innate sensors such as Toll-like receptors through detection of bacterial products activates the production of reactive oxygen species and pro-inflammatory cytokines such as TNF- $\alpha$, IL-1 $\beta$, and IL- 12 by monocytes, ${ }^{135}$ which are mediators found in amniotic fluid of women with preterm labor and intra-amniotic infection. ${ }^{38,39,54,104-106,136}$ A recent study demonstrated that placental macrophages can respond to microbes by releasing extracellular traps (METs), ${ }^{137}$ suggesting that monocytes/ macrophages in the amniotic cavity may have other functions in addition to cytokine release. Yet, the question of whether amniotic fluid monocytes/macrophages are predominantly of maternal or fetal origin, especially in the context of intra-amniotic infection, remains unanswered.

Monocytes/macrophages were present, albeit in lesser numbers, in amniotic fluid of women with preterm labor and intra-amniotic inflammation, providing further confirmation that the intra-amniotic inflammatory process is less severe in the absence of culturable microorganisms. ${ }^{34,43,125}$ In tissues, resident macrophages act as sentinels, orchestrating the clearance of damaged cells to maintain homeostasis. ${ }^{138}$ This sentinel-like function relies, in part, on the variety of pattern recognition receptors (eg, Toll-like receptors) and cytosolic receptors (eg, NLRP3) expressed by macrophages. ${ }^{139-141}$ Macrophages, therefore, are considered to be the first to detect danger signals or alarmins released by damaged cells. ${ }^{132}$ This concept was demonstrated by a murine study showing that sterile inflammation in response to cell death is driven by macrophages through the release of IL-1 $\alpha$ and IL-1 $\beta{ }^{131}$ Moreover, neutrophilic influx to the site of injury was dependent on macrophage-released cytokines, as deficient mice lacked such infiltration. ${ }^{131}$ These findings provide a model in which macrophages are the initiators of sterile inflammation that is followed by neutrophil recruitment. ${ }^{132}$ Similarly, amniotic fluid monocytes/macrophages may be acting as sentinels, responding to alarmins released upon cellular senescence of placental/fetal tissues ${ }^{142}$ which, in turn, will induce pro-inflammatory immune responses and recruit more immune cells (eg, neutrophils) into the amniotic cavity (ie, sterile intra-amniotic inflammation), inducing preterm labor and birth. Yet, further research is required to test this hypothesis. In support of this concept, it has been suggested that fetal macrophages may initiate parturition. ${ }^{143,144}$

The molecular mechanisms of sterile inflammation in the amniotic cavity $^{32-34}$ are thought to involve the NLRP3 inflammasome. ${ }^{127,130}$ Inflammasome complexes assemble to provide a scaffold for activation of caspase- $1,{ }^{145-163}$ which, in turn, cleaves pro-IL-1 $\beta$ and pro-IL-18 into their mature and active forms. ${ }^{164-171}$ Inflammasome activation can result in an inflammatory type of cell death, referred to as pyroptosis, ${ }^{172-175}$ in which the molecule gasdermin D forms pores in the host cell membrane, ${ }^{173,176-179}$ allowing for the release of cytosolic proteins such as IL-1 $\beta{ }^{166,169}$ Pyroptosis was originally described in macrophages, ${ }^{172,173,180}$ and we recently demonstrated that the effector molecule of pyroptosis, gasdermin $D$, is present in amniotic fluid of women with preterm labor and sterile intra-amniotic inflammation. ${ }^{125}$ Herein, we propose that amniotic fluid monocytes/macrophages undergo inflammasome-mediated pyroptosis, a potential mechanism for sterile intra-amniotic inflammation in women with preterm labor.

Collectively, these findings indicate that amniotic fluid monocytes/macrophages play different roles in subsets of women with preterm labor: While cytokine release and MET formation are central to intra-amniotic infection, inflammasome-mediated pyroptosis occurs in the setting of sterile intra-amniotic inflammation.

\subsection{Amniotic fluid CD4 ${ }^{+} \mathrm{T}$ cells in women with preterm labor and intra-amniotic infection or intra- amniotic inflammation}

In the current study, we found that $\mathrm{CD} 4^{+} \mathrm{T}$ cells, but not $\mathrm{CD} 8^{+} \mathrm{T}$ cells, are increased in women with preterm labor and intra-amniotic infection compared to those with intra-amniotic inflammation. This is consistent with our previous report showing that T cells are one of the dominant immune cell populations present in the amniotic fluid of women in preterm gestation. ${ }^{55}$ These adaptive cells are likely derived from the fetus, as amniotic fluid neutrophils in preterm gestation are predominantly of fetal origin; ${ }^{82}$ however, their origin has yet to be elucidated. Our findings are in line with previous reports showing that fetal immune activation occurs in preterm labor ${ }^{181,182}$ and that a population of central memory CD4 ${ }^{+}$ $T$ cells is increased in the cord blood of preterm neonates born to women with preterm labor. ${ }^{183}$ Such a fetal T-cell response could be initiated by in utero exposure to pathogens ${ }^{184-186}$ and/or maternal antigens. ${ }^{183,187}$ The mechanisms whereby fetal T cells could initiate 
preterm parturition involve the secretion of pro-inflammatory mediators, such as IFN- $\gamma$ and TNF- $\alpha$, and the activation of myometrial contractility. ${ }^{183}$ Whether fetal T-cell activation is implicated in the mechanisms leading to preterm labor and birth in the absence of intra-amniotic infection/inflammation is still unknown.

\section{5 | CONCLUSION}

In the current study, we report that women with spontaneous preterm labor and intra-amniotic infection had increased numbers of amniotic fluid neutrophils, monocytes/macrophages, and $\mathrm{CD}^{+} \mathrm{T}$ cells compared to those with intra-amniotic inflammation. Such cellular immune responses were accompanied by elevated amniotic fluid concentrations of IL-6, IL-1 $\beta$, and IL-10. These results provide evidence that the cellular immune responses observed in women with preterm labor and intra-amniotic infection are more severe than in those with intra-amniotic inflammation, and that neutrophils, monocytes/macrophages, and $\mathrm{CD}^{+} \mathrm{T}$ cells are the main immune cells responding to microorganisms invading the amniotic cavity.

\section{ACKNOWLEDGMENTS}

We gratefully acknowledge the PRB Translational Research Laboratory for their contributions to the execution of this study. We thank the physicians and nurses from the Center for Advanced Obstetrical Care and Research and the Intrapartum Unit for their help in collecting human samples. The authors also thank the staff members of the PRB Clinical Laboratory and the PRB Histology/Pathology Unit for the processing and examination of the pathological sections.

\section{CONFLICT OF INTEREST}

The authors report no conflicts of interest.

\section{ORCID}

Nardhy Gomez-Lopez (iD https://orcid.org/0000-0002-3406-5262

Roberto Romero (iD https://orcid.org/0000-0002-4448-5121

\section{REFERENCES}

1. Blencowe $\mathrm{H}$, Cousens $\mathrm{S}$, Oestergaard $\mathrm{MZ}$, et al. National, regional, and worldwide estimates of preterm birth rates in the year 2010 with time trends since 1990 for selected countries: a systematic analysis and implications. Lancet. 2012;379(9832):2162-2172.

2. Monier I, Ancel PY, Ego A, et al. Fetal and neonatal outcomes of preterm infants born before 32 weeks of gestation according to antenatal vs postnatal assessments of restricted growth. Am J Obstet Gynecol. 2017;216(5):516.e511-516.e510.

3. Joseph RM, Korzeniewski SJ, Allred EN, et al. Extremely low gestational age and very low birthweight for gestational age are risk factors for autism spectrum disorder in a large cohort study of 10-year-old children born at 23-27 weeks' gestation. Am J Obstet Gynecol. 2017;216(3):304.e301-304.e316.

4. Chawanpaiboon S, Vogel JP, Moller AB, et al. Global, regional, and national estimates of levels of preterm birth in 2014: a systematic review and modelling analysis. Lancet Glob Health. 2018. 7(1):e37-e46.

5. Travers CP, Carlo WA, McDonald SA, et al. Mortality and pulmonary outcomes of extremely preterm infants exposed to antenatal corticosteroids. Am J Obstet Gynecol. 2018;218(1):130.e131-130.e113.

6. Goldenberg RL, Culhane JF, lams JD, Romero R. Epidemiology and causes of preterm birth. Lancet. 2008;371(9606):75-84.

7. Romero R, Dey SK, Fisher SJ. Preterm labor: one syndrome, many causes. Science. 2014;345(6198):760-765.

8. Gravett MG, Hummel D, Eschenbach DA, Holmes KK. Preterm labor associated with subclinical amniotic fluid infection and with bacterial vaginosis. Obstet Gynecol. 1986;67(2):229-237.

9. Romero R, Mazor M, Wu YK, et al. Infection in the pathogenesis of preterm labor. Semin Perinatol. 1988;12(4):262-279.

10. Romero R, Sirtori M, Oyarzun E, et al. Infection and labor. V. Prevalence, microbiology, and clinical significance of intraamniotic infection in women with preterm labor and intact membranes. Am J Obstet Gynecol. 1989;161(3):817-824.

11. Gravett MG, Witkin SS, Haluska GJ, Edwards JL, Cook MJ, Novy MJ. An experimental model for intraamniotic infection and preterm labor in rhesus monkeys. Am J Obstet Gynecol. 1994;171(6):1660-1667.

12. Gomez R, Romero R, Edwin SS, David C. Pathogenesis of preterm labor and preterm premature rupture of membranes associated with intraamniotic infection. Infect Dis Clin North Am. 1997;11(1):135-176.

13. Kallapur SG, Willet KE, Jobe $A H$, Ikegami $M$, Bachurski CJ. Intra-amniotic endotoxin: chorioamnionitis precedes lung maturation in preterm lambs. Am J Physiol Lung Cell Mol Physiol. 2001;280(3):L527-536.

14. Novy MJ, Duffy L, Axthelm MK, et al. Ureaplasma parvum or Mycoplasma hominis as sole pathogens cause chorioamnionitis, preterm delivery, and fetal pneumonia in rhesus macaques. Reprod Sci. 2009;16(1):56-70.

15. Whidbey C, Harrell MI, Burnside K, et al. A hemolytic pigment of Group B Streptococcus allows bacterial penetration of human placenta. J Exp Med. 2013;210(6):1265-1281.

16. Combs CA, Gravett M, Garite TJ, et al. Amniotic fluid infection, inflammation, and colonization in preterm labor with intact membranes. Am J Obstet Gynecol. 2014;210(2):125.e121-125.e115.

17. Cobo T, Kacerovsky M, Jacobsson B. Amniotic fluid infection, inflammation, and colonization in preterm labor with intact membranes. Am J Obstet Gynecol. 2014;211(6):708.

18. Bobitt JR, Ledger WJ. Unrecognized amnionitis and prematurity: a preliminary report. J Reprod Med. 1977;19(1):8-12.

19. Bobitt JR, Hayslip CC, Damato JD. Amniotic fluid infection as determined by transabdominal amniocentesis in patients with intact membranes in premature labor. Am J Obstet Gynecol. 1981;140(8):947-952.

20. Wallace RL, Herrick CN. Amniocentesis in the evaluation of premature labor. Obstet Gynecol. 1981;57(4):483-486.

21. Wahbeh CJ, Hill GB, Eden RD, Gall SA. Intra-amniotic bacterial colonization in premature labor. Am J Obstet Gynecol. 1984;148(6):739-743.

22. Romero R, Mazor M. Infection and preterm labor. Clin Obstet Gynecol. 1988;31(3):553-584.

23. Romero R, Avila C, Brekus CA, Morotti R. The role of systemic and intrauterine infection in preterm parturition. Ann N Y Acad Sci. 1991;622:355-375

24. Gibbs RS, Romero R, Hillier SL, Eschenbach DA, Sweet RL. A review of premature birth and subclinical infection. Am J Obstet Gynecol. 1992;166(5):1515-1528. 
25. Watts DH, Krohn MA, Hillier SL, Eschenbach DA. The association of occult amniotic fluid infection with gestational age and neonatal outcome among women in preterm labor. Obstet Gynecol. 1992;79(3):351-357.

26. Romero R, Gomez R, Chaiworapongsa T, Conoscenti G, Kim JC, Kim YM. The role of infection in preterm labour and delivery. Paediatr Perinat Epidemiol. 2001;15(Suppl 2):41-56.

27. Yoon BH, Romero R, Moon JB, et al. Clinical significance of intraamniotic inflammation in patients with preterm labor and intact membranes. Am J Obstet Gynecol. 2001;185(5):1130-1136.

28. Romero R, Espinoza J, Chaiworapongsa T, Kalache K. Infection and prematurity and the role of preventive strategies. Semin Neonatol. 2002;7(4):259-274.

29. Gravett MG, Novy MJ, Rosenfeld RG, et al. Diagnosis of intra-amniotic infection by proteomic profiling and identification of novel biomarkers. JAMA. 2004;292(4):462-469.

30. Shim S-S, Romero R, Hong J-S, et al. Clinical significance of intraamniotic inflammation in patients with preterm premature rupture of membranes. Am J Obstet Gynecol. 2004;191(4):1339-1345.

31. Romero R, Miranda J, Chaiworapongsa T, et al. A novel molecular microbiologic technique for the rapid diagnosis of microbial invasion of the amniotic cavity and intra-amniotic infection in preterm labor with intact membranes. Am J Reprod Immunol. 2014;71(4):330-358.

32. Romero R, Miranda J, Chaiworapongsa T, et al. Prevalence and clinical significance of sterile intra-amniotic inflammation in patients with preterm labor and intact membranes. Am J Reprod Immunol. 2014;72(5):458-474.

33. Romero R, Miranda J, Chaemsaithong $\mathrm{P}$, et al. Sterile and microbial-associated intra-amniotic inflammation in preterm prelabor rupture of membranes. J Matern Fetal Neonatal Med. 2015;28(12):1394-1409.

34. Gomez-Lopez N, Romero R, Panaitescu B, et al. Inflammasome activation during spontaneous preterm labor with intra-amniotic infection or sterile intra-amniotic inflammation. Am J Reprod Immunol. 2018;80(5):e13049.

35. Matzinger P. An innate sense of danger. Semin Immunol. 1998;10(5):399-415.

36. Oppenheim JJ, Yang D. Alarmins: chemotactic activators of immune responses. Curr Opin Immunol. 2005;17(4):359-365.

37. Lotze MT, Deisseroth A, Rubartelli A. Damage associated molecular pattern molecules. Clin Immunol. 2007;124(1):1-4.

38. Romero R, Brody DT, Oyarzun E, et al. Interleukin-1: a signal for the onset of parturition. Am J Obstet Gynecol. 1989;160(5 Pt 1):1117-1123

39. Romero R, Mazor M, Brandt F, et al. Interleukin-1 alpha and interleukin-1 beta in preterm and term human parturition. Am J Reprod Immunol. 1992;27(3-4):117-123.

40. Friel LA, Romero R, Edwin S, et al. The calcium binding protein, $\mathrm{S} 100 \mathrm{~B}$, is increased in the amniotic fluid of women with intra-amniotic infection/inflammation and preterm labor with intact or ruptured membranes. J Perinat Med. 2007;35(5):385-393.

41. Chaiworapongsa T, Erez O, Kusanovic JP, et al. Amniotic fluid heat shock protein 70 concentration in histologic chorioamnionitis, term and preterm parturition. J Matern Fetal Neonatal Med. 2008;21(7):449-461.

42. Romero R, Chaiworapongsa T, Alpay Savasan Z, et al. Damage-associated molecular patterns (DAMPs) in preterm labor with intact membranes and preterm PROM: a study of the alarmin HMGB1. $J$ Matern Fetal Neonatal Med. 2011;24(12):1444-1455.

43. Romero R, Grivel J-C, Tarca AL, et al. Evidence of perturbations of the cytokine network in preterm labor. Am J Obstet Gynecol. 2015;213(6):836.e831-836.e818.

44. Oh KJ, Kim SM, Hong JS, et al. Twenty-four percent of patients with clinical chorioamnionitis in preterm gestations have no evidence of either culture-proven intraamniotic infection or intraamniotic inflammation. Am J Obstet Gynecol. 2017;216(6):604 e601-604 e611.

45. Yoon BH, Romero R, Park JY, et al. Antibiotic administration can eradicate intra-amniotic infection or intra-amniotic inflammation in a subset of patients with preterm labor and intact membranes. Am J Obstet Gynecol. 2019;221(2):142.e1-142.e22.

46. Neggers YH. Trends in maternal mortality in the United States. Reprod Toxicol. 2016;64:72-76.

47. de Graaf MT, de Jongste AH, Kraan J, Boonstra JG, Sillevis Smitt PA, Gratama JW. Flow cytometric characterization of cerebrospinal fluid cells. Cytometry B Clin Cytom. 2011;80(5):271-281.

48. Jaime-Pérez JC, Borrego-López MF, Jiménez-Castillo RA, et al. Comparison of conventional cytomorphology, flow cytometry immunophenotyping, and automated cell counting of CSF for detection of CNS involvement in acute lymphoblastic leukemia. Int J Lab Hematol. 2018;40(2):169-174.

49. Duong HP, Wissing KM, Tram N, Mascart G, Lepage P, Ismaili K. Accuracy of automated flow cytometry-based leukocyte counts to rule out urinary tract infection in febrile children: a prospective cross-sectional study. J Clin Microbiol. 2016;54(12):2975-2981.

50. Garcia-Coca M, Gadea I, Esteban J. Relationship between conventional culture and flow cytometry for the diagnosis of urinary tract infection. J Microbiol Methods. 2017;137:14-18

51. Broeren M, Nowacki R, Halbertsma F, Arents N, Zegers S. Urine flow cytometry is an adequate screening tool for urinary tract infections in children. Eur J Pediatr. 2018;178(3):363-368.

52. van de Geijn GM, van Gent M, van Pul-Bom N, Beunis MH, van Tilburg AJ, Njo TL. A new flow cytometric method for differential cell counting in ascitic fluid. Cytometry B Clin Cytom. 2016;90(6):506-511.

53. Brooks CR, van Dalen CJ, Hermans IF, Douwes J. Identifying leukocyte populations in fresh and cryopreserved sputum using flow cytometry. Cytometry B Clin Cytom. 2013;84(2):104-113.

54. Martinez-Varea A, Romero R, Xu Yl, et al. Clinical chorioamnionitis at term VII: the amniotic fluid cellular immune response. J Perinat Med. 2017;45(5):523-538.

55. Gomez-Lopez N, Romero R, Xu YI, et al. The immunophenotype of amniotic fluid leukocytes in normal and complicated pregnancies. Am J Reprod Immunol. 2018;79(4):e12827.

56. Marquardt N, Ivarsson MA, Sundstrom E, et al. Fetal CD103 ${ }^{+}$ IL-17-producing group 3 innate lymphoid cells represent the dominant lymphocyte subset in human amniotic fluid. J Immunol. 2016:197(8):3069-3075.

57. Romero R, Shamma F, Avila C, et al. Infection and labor. VI. Prevalence, microbiology, and clinical significance of intraamniotic infection in twin gestations with preterm labor. Am J Obstet Gynecol. 1990;163(3):757-761.

58. Romero R, Ghidini A, Mazor M, Behnke E. Microbial invasion of the amniotic cavity in premature rupture of membranes. Clin Obstet Gynecol. 1991;34(4):769-778.

59. Chaemsaithong P, Romero R, Korzeniewski SJ, et al. A rapid interleukin- 6 bedside test for the identification of intra-amniotic inflammation in preterm labor with intact membranes. J Matern Fetal Neonatal Med. 2016;29(3):349-359.

60. Chaemsaithong P, Romero R, Korzeniewski SJ, et al. A point of care test for interleukin- 6 in amniotic fluid in preterm prelabor rupture of membranes: a step toward the early treatment of acute intraamniotic inflammation/infection. J Matern Fetal Neonatal Med. 2016;29(3):360-367.

61. Romero R, Chaemsaithong P, Chaiyasit N, et al. CXCL10 and IL- 6: markers of two different forms of intra-amniotic inflammation in preterm labor. Am J Reprod Immunol. 2017;78(1):e12685.

62. Varrey A, Romero R, Panaitescu B, et al. Human beta-defensin-1: a natural antimicrobial peptide present in amniotic fluid that is 
increased in spontaneous preterm labor with intra-amniotic infection. Am J Reprod Immunol. 2018;80(4):e13031.

63. Gomez-Lopez N, Romero R, Maymon E, et al. Clinical chorioamnionitis at term IX: in vivo evidence of intra-amniotic inflammasome activation. J Perinat Med. 2019;47(3):276-287.

64. Para R, Romero R, Miller D, et al. Human beta-defensin-3 participates in intra-amniotic host defense in women with labor at term, spontaneous preterm labor and intact membranes, and preterm prelabor rupture of membranes. J Matern Fetal Neonatal Med. 2019;1-16.

65. Romero R, Miranda J, Chaiworapongsa T, et al. Sterile intra-amniotic inflammation in asymptomatic patients with a sonographic short cervix: prevalence and clinical significance. J Matern Fetal Neonatal Med. 2014;1-17.

66. Romero R, Chaemsaithong P, Docheva N, et al. Clinical chorioamnionitis at term VI: acute chorioamnionitis and funisitis according to the presence or absence of microorganisms and inflammation in the amniotic cavity. J Perinat Med. 2016;44(1):33-51.

67. Romero R, Chaemsaithong P, Docheva N, et al. Clinical chorioamnionitis at term $\mathrm{V}$ : umbilical cord plasma cytokine profile in the context of a systemic maternal inflammatory response. J Perinat Med. 2016;44(1):53-76.

68. Romero R, Chaemsaithong P, Docheva N, et al. Clinical chorioamnionitis at term IV: the maternal plasma cytokine profile. J Perinat Med. 2016;44(1):77-98.

69. Romero R, Chaemsaithong P, Korzeniewski SJ, et al. Clinical chorioamnionitis at term III: how well do clinical criteria perform in the identification of proven intra-amniotic infection? J Perinat Med 2016:44(1):23-32.

70. Romero R, Chaemsaithong P, Korzeniewski SJ, et al. Clinical chorioamnionitis at term II: the intra-amniotic inflammatory response. J Perinat Med. 2016;44(1):5-22.

71. Chaemsaithong P, Romero R, Docheva N, et al. Comparison of rapid MMP-8 and interleukin-6 point-of-care tests to identify intra-amniotic inflammation/infection and impending preterm delivery in patients with preterm labor and intact membranes(). $J$ Matern Fetal Neonatal Med. 2018;31(2):228-244.

72. Kusanovic JP, Romero R, Martinovic C, et al. Transabdominal collection of amniotic fluid "sludge" and identification of Candida albicans intra-amniotic infection. J Matern Fetal Neonatal Med. 2018;31(10):1279-1284

73. Oh KJ, Romero R, Park JY, Kang J, Hong JS, Yoon BH. A high concentration of fetal fibronectin in cervical secretions increases the risk of intra-amniotic infection and inflammation in patients with preterm labor and intact membranes. J Perinat Med. 2019;47(3):288-303

74. Pacora $\mathrm{P}$, Romero R, Erez $\mathrm{O}$, et al. The diagnostic performance of the beta-glucan assay in the detection of intra-amniotic infection with Candida species. J Matern Fetal Neonatal Med. 2019;32(10):1703-1720.

75. Kim CJ, Romero R, Chaemsaithong P, Chaiyasit N, Yoon BH, Kim YM. Acute chorioamnionitis and funisitis: definition, pathologic features, and clinical significance. Am J Obstet Gynecol. 2015;213(4 Suppl):S29-52.

76. Romero R, Kim YM, Pacora P, et al. The frequency and type of placental histologic lesions in term pregnancies with normal outcome. J Perinat Med. 2018;46(6):613-630

77. Redline RW. Classification of placental lesions. Am J Obstet Gynecol. 2015;213(4 Suppl):S21-28.

78. Romero R, Quintero R, Nores J, et al. Amniotic fluid white blood cell count: a rapid and simple test to diagnose microbial invasion of the amniotic cavity and predict preterm delivery. Am J Obstet Gynecol. 1991;165(4 Pt 1):821-830.
79. Romero R, Emamian M, Quintero R, et al. The value and limitations of the Gram stain examination in the diagnosis of intraamniotic infection. Am J Obstet Gynecol. 1988;159(1):114-119.

80. Romero R, Jimenez C, Lohda AK, et al. Amniotic fluid glucose concentration: a rapid and simple method for the detection of intraamniotic infection in preterm labor. Am J Obstet Gynecol. 1990;163(3):968-974.

81. Romero R, Ceska M, Avila C, Mazor M, Behnke E, Lindley I. Neutrophil attractant/activating peptide-1/interleukin-8 in term and preterm parturition. Am J Obstet Gynecol. 1991;165(4 Pt 1):813-820

82. Gomez-Lopez N, Romero R, Xu YI, et al. Are amniotic fluid neutrophils in women with intraamniotic infection and/or inflammation of fetal or maternal origin? Am J Obstet Gynecol. 2017;217(6):693 e691-693 e616.

83. Mayadas TN, Cullere X, Lowell CA. The multifaceted functions of neutrophils. Annu Rev Pathol. 2014;9:181-218.

84. Liew PX, Kubes P. The neutrophil's role during health and disease. Physiol Rev. 2019;99(2):1223-1248.

85. Novakovic TR, Dolicanin ZC, Djordjevic NZ. Effects of maternal subclinical hypothyroidism on amniotic fluid cells oxidative status. Reprod Toxicol. 2018;78:97-101.

86. Heine RP, Wiesenfeld H, Mortimer L, Greig PC. Amniotic fluid defensins: potential markers of subclinical intrauterine infection. Clin Infect Dis. 1998;27(3):513-518.

87. Espinoza J, Chaiworapongsa T, Romero R, et al. Antimicrobial peptides in amniotic fluid: defensins, calprotectin and bacterial/ permeability-increasing protein in patients with microbial invasion of the amniotic cavity, intra-amniotic inflammation, preterm labor and premature rupture of membranes. J Matern Fetal Neonatal Med. 2003;13(1):2-21.

88. Akinbi HT, Narendran V, Pass AK, Markart P, Hoath SB. Host defense proteins in vernix caseosa and amniotic fluid. Am J Obstet Gynecol. 2004;191(6):2090-2096.

89. Romero R, Kusanovic JP, Gotsch F, et al. Isobaric labeling and tandem mass spectrometry: a novel approach for profiling and quantifying proteins differentially expressed in amniotic fluid in preterm labor with and without intra-amniotic infection/inflammation. $J$ Matern Fetal Neonatal Med. 2010;23(4):261-280.

90. Myntti T, Rahkonen L, Nupponen I, et al. Amniotic fluid infection in preterm pregnancies with intact membranes. Dis Markers. 2017;2017:8167276.

91. Musilova I, Andrys C, Drahosova M, et al. Amniotic fluid cathepsin-Gin pregnancies complicated by the preterm prelabor rupture of membranes. J Matern Fetal Neonatal Med. 2017;30(17):2097-2104.

92. Rivero-Marcotegui A, Larranaga-Azcarate C, Ceres-Ruiz R, GarciaMerlo S. Polymorphonuclear elastase and interleukin-6 in amniotic fluid in preterm labor. Clin Chem. 1997;43(5):857-859.

93. Helmig BR, Romero R, Espinoza J, et al. Neutrophil elastase and secretory leukocyte protease inhibitor in prelabor rupture of membranes, parturition and intra-amniotic infection. J Matern Fetal Neonatal Med. 2002;12(4):237-246.

94. Pacora P, Maymon E, Gervasi MT, et al. Lactoferrin in intrauterine infection, human parturition, and rupture of fetal membranes. Am J Obstet Gynecol. 2000;183(4):904-910.

95. Musilova I, Andrys C, Krejsek J, et al. Amniotic fluid pentraxins: potential early markers for identifying intra-amniotic inflammatory complications in preterm pre-labor rupture of membranes. Am J Reprod Immunol. 2018;79(5):e12789.

96. Gomez-Lopez N, Romero R, Garcia-Flores V, et al. Amniotic fluid neutrophils can phagocytize bacteria: a mechanism for microbial killing in the amniotic cavity. Am J Reprod Immunol. 2017;78(4):e12723. 
97. Gomez-Lopez N, Romero R, Xu Y, et al. Neutrophil extracellular traps in the amniotic cavity of women with intra-amniotic infection: a new mechanism of host defense. Reprod Sci. 2017;24(8):1139-1153.

98. Gomez-Lopez N, Romero R, Leng Y, et al. Neutrophil extracellular traps in acute chorioamnionitis: a mechanism of host defense. Am J Reprod Immunol. 2017;77(3):e12617.

99. Boldenow E, Gendrin C, Ngo L et al. Group B Streptococcus circumvents neutrophils and neutrophil extracellular traps during amniotic cavity invasion and preterm labor. Sci Immunol. 2016;1(4): pii: eaah4576.

100. Cherouny PH, Pankuch GA, Romero R, et al. Neutrophil attractant/ activating peptide-1/interleukin-8: association with histologic chorioamnionitis, preterm delivery, and bioactive amniotic fluid leukoattractants. Am J Obstet Gynecol. 1993;169(5):1299-1303.

101. Osmers RG, Blaser J, Kuhn W, Tschesche H. Interleukin-8 synthesis and the onset of labor. Obstet Gynecol. 1995;86(2):223-229.

102. Elliott CL, Loudon JA, Brown N, Slater DM, Bennett PR, Sullivan $\mathrm{MH}$. IL-1beta and IL-8 in human fetal membranes: changes with gestational age, labor, and culture conditions. Am J Reprod Immunol. 2001;46(4):260-267.

103. Gomez-Lopez N, Tong W-C, Arenas-Hernandez M, et al. Chemotactic activity of gestational tissues through late pregnancy, term labor, and RU486-induced preterm labor in Guinea pigs. Am J Reprod Immunol. 2015;73(4):341-352.

104. Romero R, Manogue KR, Mitchell MD, etal. Cachectin-tumor necrosis factor in the amniotic fluid of women with intraamniotic infection and preterm labor. Am J Obstet Gynecol. 1989;161(2):336-341.

105. Romero R, Mazor M, Sepulveda W, Avila C, Copeland D, Williams J. Tumor necrosis factor in preterm and term labor. Am J Obstet Gynecol. 1992;166(5):1576-1587.

106. Thomakos N, Daskalakis G, Papapanagiotou A, Papantoniou N, Mesogitis S, Antsaklis A. Amniotic fluid interleukin-6 and tumor necrosis factor-alpha at mid-trimester genetic amniocentesis: relationship to intra-amniotic microbial invasion and preterm delivery. Eur J Obstet Gynecol Reprod Biol. 2010;148(2):147-151.

107. Romero R, Gomez R, Galasso M, et al. Macrophage inflammatory protein-1 alpha in term and preterm parturition: effect of microbial invasion of the amniotic cavity. Am J Reprod Immunol. 1994;32(2):108-113.

108. Dudley DJ, Hunter C, Mitchell MD, Varner MW. Elevations of amniotic fluid macrophage inflammatory protein-1 alpha concentrations in women during term and preterm labor. Obstet Gynecol. 1996;87(1):94-98.

109. Kacerovsky M, Celec P, Vlkova B, et al. Amniotic fluid protein profiles of intraamniotic inflammatory response to Ureaplasma spp. and other bacteria. PLoS ONE. 2013;8(3):e60399.

110. Romero R, Mazor M, Tartakovsky B. Systemic administration of interleukin-1 induces preterm parturition in mice. Am J Obstet Gynecol. 1991;165(4 Pt 1):969-971.

111. Romero R, Sepulveda W, Mazor M, et al. The natural interleukin-1 receptor antagonist in term and preterm parturition. Am J Obstet Gynecol. 1992;167(4 Pt 1):863-872.

112. Witkin SS, Gravett MG, Haluska GJ, Novy MJ. Induction of interleukin-1 receptor antagonist in rhesus monkeys after intraamniotic infection with group B streptococci or interleukin-1 infusion. Am J Obstet Gynecol. 1994;171(6):1668-1672.

113. Baggia S, Gravett MG, Witkin SS, Haluska GJ, Novy MJ. Interleukin-1 beta intra-amniotic infusion induces tumor necrosis factor-alpha, prostaglandin production, and preterm contractions in pregnant rhesus monkeys. J Soc Gynecol Investig. 1996;3(3):121-126.

114. Vadillo-Ortega F, Sadowsky DW, Haluska GJ, et al. Identification of matrix metalloproteinase-9 in amniotic fluid and amniochorion in spontaneous labor and after experimental intrauterine infection or interleukin-1 beta infusion in pregnant rhesus monkeys. Am J Obstet Gynecol. 2002;186(1):128-138.

115. Sadowsky DW, Adams KM, Gravett MG, Witkin SS, Novy MJ. Preterm labor is induced by intraamniotic infusions of interleukin-1beta and tumor necrosis factor-alpha but not by interleukin-6 or interleukin-8 in a nonhuman primate model. Am J Obstet Gynecol. 2006;195(6):1578-1589.

116. Aagard K, Ganu R, Ma J, et al. Intraamniotic interleukin-1 (IL1 $\beta$ ) induces histologic chorioamnionitis and alters the microbiome in a primate model of inflammatory preterm birth. Am J Obstet Gynecol. 2013;208(1):S218.

117. Prince A, Ma J, Miller L, et al. Chorioamnionitis induced by intraamniotic injection of IL1, LPS, or Ureaplasma parvum is associated with an altered microbiome in a primate model of inflammatory preterm birth. Am J Obstet Gynecol. 2015;212(1):S153.

118. Presicce P, Senthamaraikannan P, Alvarez M, et al. Neutrophil recruitment and activation in decidua with intra-amniotic IL-1beta in the preterm rhesus macaque. Biol Reprod. 2015;92(2):56.

119. Faro J, Romero R, Schwenkel G, et al. Intra-amniotic inflammation induces preterm birth by Activating the NLRP3 inflammasome. Biol Reprod. 2018;100(5):1290-1305.

120. Russel P. Inflammatory lesions of the human placenta. I. Clinical significance of acute chorioamnionitis. Am J Diagn Gynecol Obstet. 1978;2:127-137.

121. Guzick DS, Winn K. The association of chorioamnionitis with preterm delivery. Obstet Gynecol. 1985;65(1):11-16.

122. Hoeven $\mathrm{KHV}$, Anyaegbunam A, Hochster H, et al. Clinical significance of increasing histologic severity of acute inflammation in the fetal membranes and umbilical cord. Pediatr Pathol Lab Med. 1996;16(5):731-744.

123. Gomez-Lopez N, Romero R, Xu YI, et al. A role for the inflammasome in spontaneous preterm labor with acute histologic chorioamnionitis. Reprod Sci. 2017;24(10):1382-1401.

124. Romero R, Chaiworapongsa T, Alpay Savasan Z, et al. Clinical chorioamnionitis is characterized by changes in the expression of the alarmin HMGB1 and one of its receptors, sRAGE. J Matern Fetal Neonatal Med. 2012;25(6):558-567.

125. Gomez-Lopez N, Romero R, Tarca AL, et al.Gasdermin D: evidence of pyroptosis in spontaneous preterm labor with sterile intraamniotic inflammation or intra-amniotic infection. Am J Reprod Immunol. Accepted Aug 22, 2019.

126. Gomez-Lopez N, Romero R, Plazyo O, et al. Intra-amniotic administration of HMGB1 induces spontaneous preterm labor and birth. Am J Reprod Immunol. 2016;75(1):3-7.

127. Gomez-Lopez N, Romero R, Garcia-Flores V, et al. Inhibition of the NLRP3 inflammasome can prevent sterile intra-amniotic inflammation, preterm labor/birth and adverse neonatal outcomes. Biol Reprod. 2018;100(5):1306-1318.

128. Gomez-Lopez N, Romero R, Arenas-Hernandez M, et al. Intra-amniotic administration of lipopolysaccharide induces spontaneous preterm labor and birth in the absence of a body temperature change. J Matern Fetal Neonatal Med. 2018;31(4):439-446.

129. Garcia-Flores V, Romero R, Miller D, et al. Inflammation-induced adverse pregnancy and neonatal outcomes can be improved by the immunomodulatory peptide exendin-4. Front Immunol. 2018;9:1291.

130. Plazyo O, Romero R, Unkel R, et al. HMGB1 induces an inflammatory response in the chorioamniotic membranes that is partially mediated by the inflammasome. Biol Reprod. 2016;95(6):130.

131. Kono H, Karmarkar D, Iwakura Y, Rock KL. Identification of the cellular sensor that stimulates the inflammatory response to sterile cell death. J Immunol. 2010;184(8):4470-4478.

132. Peiseler M, Kubes P. Macrophages play an essential role in traumainduced sterile inflammation and tissue repair. Eur J Trauma Emerg Surg. 2018:44(3):335-349. 
133. DiGiulio DB, Romero R, Amogan HP, et al. Microbial prevalence, diversity and abundance in amniotic fluid during preterm labor: a molecular and culture-based investigation. PLOS ONE. 2008;3(8):e3056.

134. Gardella C, Riley DE, Hitti J, Agnew K, Krieger JN, Eschenbach D. Identification and sequencing of bacterial rDNAs in culture-negative amniotic fluid from women in premature labor. Am J Perinatol. 2004;21(6):319-323.

135. Gordon S, Taylor PR. Monocyte and macrophage heterogeneity. Nat Rev Immunol. 2005;5(12):953-964.

136. Revello R, Alcaide MJ, Dudzik D, Abehsera D, Bartha JL. Differential amniotic fluid cytokine profile in women with chorioamnionitis with and without funisitis. J Matern Fetal Neonatal Med. 2016;29(13):2161-2165.

137. Doster RS, Sutton JA, Rogers LM, Aronoff DM, Gaddy JA. Streptococcus agalactiae induces placental macrophages to release extracellular traps loaded with tissue remodeling enzymes via an oxidative burst-dependent mechanism. MBio. 2018;9(6):pii: e02084-18.

138. Davies LC, Jenkins SJ, Allen JE, Taylor PR. Tissue-resident macrophages. Nat Immunol. 2013;14(10):986-995.

139. Akira S, Takeda K, Kaisho T. Toll-like receptors: critical proteins linking innate and acquired immunity. Nat Immunol. 2001;2(8):675-680.

140. Inohara N, Nunez G. NODs: intracellular proteins involved in inflammation and apoptosis. Nat Rev Immunol. 2003;3(5):371-382.

141. Tschopp J, Martinon F, Burns K. NALPs: a novel protein family involved in inflammation. Nat Rev Mol Cell Biol. 2003;4(2):95-104.

142. Gomez-Lopez N, Romero R, Plazyo O, et al. Preterm labor in the absence of acute histologic chorioamnionitis is characterized by cellular senescence of the chorioamniotic membranes. Am J Obstet Gynecol. 2017;217(5):592 e591-592 e517.

143. Condon JC, Jeyasuria P, Faust JM, Mendelson CR. Surfactant protein secreted by the maturing mouse fetal lung acts as a hormone that signals the initiation of parturition. Proc Natl Acad Sci U S A 2004;101(14):4978-4983.

144. Mendelson CR, Montalbano AP, Gao L. Fetal-to-maternal signaling in the timing of birth. J Steroid Biochem Mol Biol. 2017;170:19-27.

145. Martinon F, Burns K, Tschopp J. The inflammasome: a molecular platform triggering activation of inflammatory caspases and processing of prolL-beta. Mol Cell. 2002;10(2):417-426.

146. Petrilli V, Papin S, Tschopp J. The inflammasome. Curr Biol. 2005;15(15):R581.

147. Ogura Y, Sutterwala FS, Flavell RA. The inflammasome: first line of the immune response to cell stress. Cell. 2006;126(4):659-662.

148. Mariathasan S, Monack DM. Inflammasome adaptors and sensors: intracellular regulators of infection and inflammation. Nat Rev Immunol. 2007;7(1):31-40.

149. Stutz A, Golenbock DT, Latz E. Inflammasomes: too big to miss. $J$ Clin Invest. 2009;119(12):3502-3511.

150. Franchi L, Eigenbrod T, Munoz-Planillo R, Nunez G. The inflammasome: a caspase-1-activation platform that regulates immune responses and disease pathogenesis. Nat Immunol. 2009;10(3):241-247.

151. Jha S, Ting JP. Inflammasome-associated nucleotide-binding domain, leucine-rich repeat proteins and inflammatory diseases. $J$ Immunol. 2009;183(12):7623-7629.

152. Schroder K, Tschopp J. The inflammasomes. Cell. 2010;140(6):821-832.

153. Franchi L, Munoz-Planillo R, Reimer T, Eigenbrod T, Nunez G. Inflammasomes as microbial sensors. Eur J Immunol. 2010;40(3):611-615.

154. Gross O, Thomas CJ, Guarda G, Tschopp J. The inflammasome: an integrated view. Immunol Rev. 2011;243(1):136-151.

155. Lamkanfi M, Dixit VM. Modulation of inflammasome pathways by bacterial and viral pathogens. J Immunol. 2011;187(2):597-602.
156. Horvath GL, Schrum JE, De Nardo CM, Latz E. Intracellular sensing of microbes and danger signals by the inflammasomes. Immunol Rev. 2011;243(1):119-135

157. van de Veerdonk FL, Netea MG, Dinarello CA, Joosten LA Inflammasome activation and IL-1beta and IL-18 processing during infection. Trends Immunol. 2011;32(3):110-116.

158. Franchi L, Munoz-Planillo R, Nunez G. Sensing and reacting to microbes through the inflammasomes. Nat Immunol. 2012;13(4):325-332

159. Franchi L, Nunez G. Immunology. Orchestrating inflammasomes. Science. 2012;337(6100):1299-1300.

160. Henao-Mejia J, Elinav E, Strowig T, Flavell RA. Inflammasomes: far beyond inflammation. Nat Immunol. 2012;13(4):321-324.

161. Latz E, Xiao TS, Stutz A. Activation and regulation of the inflammasomes. Nat Rev Immunol. 2013;13(6):397-411.

162. Lamkanfi M, Dixit VM. Mechanisms and functions of inflammasomes. Cell. 2014;157(5):1013-1022.

163. Guo H, Callaway JB, Ting JP. Inflammasomes: mechanism of action, role in disease, and therapeutics. Nat Med. 2015;21(7):677-687.

164. Black RA, Kronheim SR, Merriam JE, March CJ, Hopp TP. A preaspartate-specific protease from human leukocytes that cleaves pro-interleukin-1 beta. J Biol Chem. 1989;264(10):5323-5326.

165. Kostura MJ, Tocci MJ, Limjuco G, et al. Identification of a monocyte specific pre-interleukin 1 beta convertase activity. Proc Natl Acad Sci USA. 1989;86(14):5227-5231.

166. Thornberry NA, Bull HG, Calaycay JR, et al. A novel heterodimeric cysteine protease is required for interleukin-1 beta processing in monocytes. Nature. 1992;356(6372):768-774.

167. Cerretti D, Kozlosky C, Mosley B, et al. Molecular cloning of the interleukin-1 beta converting enzyme. Science. 1992;256(5053):97-100.

168. Gu Y, Kuida K, Tsutsui $\mathrm{H}$, et al. Activation of interferon-gamma inducing factor mediated by interleukin-1beta converting enzyme. Science. 1997;275(5297):206-209.

169. Ghayur T, Banerjee S, Hugunin M, et al. Caspase-1 processes IFNgamma-inducing factor and regulates LPS-induced IFN-gamma production. Nature. 1997;386(6625):619-623.

170. Dinarello CA. Interleukin-1 beta, interleukin-18, and the interleukin-1 beta converting enzyme. Ann N Y Acad Sci. 1998;856:1-11.

171. Fantuzzi G, Dinarello CA. Interleukin-18 and interleukin-1 beta: two cytokine substrates for ICE (caspase-1). J Clin Immunol. 1999;19(1):1-11.

172. Cookson BT, Brennan MA. Pro-inflammatory programmed cell death. Trends Microbiol. 2001;9(3):113-114

173. Bergsbaken T, Fink SL, Cookson BT. Pyroptosis: host cell death and inflammation. Nat Rev Microbiol. 2009;7(2):99-109.

174. Miao EA, Rajan JV, Aderem A. Caspase-1-induced pyroptotic cell death. Immunol Rev. 2011;243(1):206-214.

175. Shalini S, Dorstyn L, Dawar S, Kumar S. Old, new and emerging functions of caspases. Cell Death Differ. 2015;22(4):526-539.

176. Gaidt MM, Hornung V. Pore formation by GSDMD is the effector mechanism of pyroptosis. EMBO J. 2016;35(20):2167-2169.

177. Sborgi L, Rühl S, Mulvihill E, et al. GSDMD membrane pore formation constitutes the mechanism of pyroptotic cell death. EMBO J. 2016;35(16):1766-1778.

178. Aglietti RA, Dueber EC. Recent insights into the molecular mechanisms underlying pyroptosis and gasdermin family functions. Trends Immunol. 2017;38(4):261-271.

179. Shi J, Gao W, Shao F. Pyroptosis: gasdermin-mediated programmed necrotic cell death. Trends Biochem Sci. 2017;42(4):245-254.

180. Fink SL, Cookson BT. Apoptosis, pyroptosis, and necrosis: mechanistic description of dead and dying eukaryotic cells. Infect Immun. 2005;73(4):1907-1916.

181. Berry SM, Romero R, Gomez R, et al. Premature parturition is characterized by in utero activation of the fetal immune system. Am J Obstet Gynecol. 1995;173(4):1315-1320. 
182. Romero R, Gomez R, Ghezzi F, et al. A fetal systemic inflammatory response is followed by the spontaneous onset of preterm parturition. Am J Obstet Gynecol. 1998;179(1):186-193.

183. Frascoli M, Coniglio L, Witt R, et al. Alloreactive fetal T cells promote uterine contractility in preterm labor via IFN-gamma and TNF-alpha. Sci Transl Med. 2018;10(438):pii: eaan2263.

184. Melville JM, Bischof RJ, Meeusen EN, Westover AJ, Moss TJ. Changes in fetal thymic immune cell populations in a sheep model of intrauterine inflammation. Reprod Sci. 2012;19(7):740-747.

185. Rueda CM, Presicce P, Jackson CM, et al. Lipopolysaccharide-induced chorioamnionitis promotes IL-1-dependent inflammatory $\mathrm{FOXP3}^{+} \mathrm{CD}^{+} \mathrm{T}$ cells in the fetal rhesus macaque. J Immunol. 2016;196(9):3706-3715.

186. Odorizzi PM, Jagannathan P, McIntyre TI, et al. In utero priming of highly functional effector T cell responses to human malaria. Sci TransI Med. 2018;10(463):pii: eaat6176.

187. Mold JE, Michaelsson J, Burt TD, et al. Maternal alloantigens promote the development of tolerogenic fetal regulatory $T$ cells in utero. Science. 2008;322(5907):1562-1565.

\section{SUPPORTING INFORMATION}

Additional supporting information may be found online in the Supporting Information section at the end of the article.

How to cite this article: Gomez-Lopez N, Romero R, Galaz J, et al. Cellular immune responses in amniotic fluid of women with preterm labor and intra-amniotic infection or intraamniotic inflammation. Am J Reprod Immunol. 2019;82:e13171. https://doi.org/10.1111/aji.13171 